\title{
OBSERVATIONS ON THE EFFECT OF VARYING TEMPERATURES ON THE FLOWERING AND FRUIT SET IN THREE VARIETIES OF GROUNDNUT')
}

\author{
G. G. BOLHUIS and W. DE GROOT \\ Laboratory of Tropical Agriculture, Wageningen
}

\begin{abstract}
SUMMARY
An investigation was made into the effect of temperature on the flowering and development of three groundnut varieties resp. from Indonesia, Mallorca and the Ukraine. No great differences in reaction to temperature were found between the varieties. Generally spreaking a temperature of $33^{\circ} \mathrm{C}$ was found to be too high for a normal development of the groundnut. On the other hand $21^{\circ} \mathrm{C}$ is too low. Differences were only found in the optimum temperature and the number of flowers formed each day. A greater tolerance to different temperatures was found as the latitude increased from which the varieties originated.
\end{abstract}

\section{INTRODUCTORY}

The effect of temperature on the development of the groundnut plant has already been the subject of several investigations (Alegre, Bouffil, Fortanier, JACOBS and TARDIEU). In these, however, use was generally made of only a single variety, so that it may be questioned as to what extent the results obtained are a criterion for other varieties which as to adaption to climate differ considerably from the varieties investigated. It is common knowledge that temperature has a marked effect on the development and behaviour of the groundnut. Since we had available three varieties of widely different origin we were able to carry out an investigation into the behaviour of these varieties at varying temperatures.

The varieties employed were:

1 The Schwarz 21 variety from Indonesia (Java), $6^{\circ}-7^{\circ}$ lat.S.

2 A variety from Mallorca, $39^{\circ}$ lat.N.

3 A variety from the Ukraine (Kiev), $51^{\circ}$ lat.N.

It will be noticed that the first variety comes from a typical tropical climate with comparatively slight fluctuations in temperature, the second variety from an island in the sub-tropics which has fairly high summer temperatures, and the third from the temperate zone characterised by the high summer temperatures of a continental climate.

In point of habit all three varieties are of the bunch type. As regards the pod shape the Indonesian and Ukrainian varieties may be considered to belong to the Spanish type, whereas the Mallorca variety is of the Valencia type.

\section{Materials AND TEchnique}

All experiments were performed in thermostatically controlled cabinets illuminated by high-pressure mercury lamps with a day-length of 12 hours. A detailed description will be found in FortanIER's thesis.

1) Received for publication July 31, 1959. 
As six cabinets were available it was possible to work at temperatures of $18^{\circ}$, $21^{\circ}, 24^{\circ}, 27^{\circ}, 30^{\circ}$ and $33^{\circ} \mathrm{C}$. In each cabinet there was room for four or five Mitscherlich pots containing one plant per pot. The growth medium was a specially compounded pot soil consisting of equal parts of clay and leaf mould to which some lime had been added. The plants were regularly watered; surplus water could drain off from below the pots. It can be assumed that as regards their moisture supply the plants were always in an optimal condition. Seeds of the first variety were laid out in a pre-germinated state, those of the two other varieties were planted after the earth in the pots had reached the temperature of the cabinet. Since the spectrum of the light employed is not normal (it contains too many blue rays and too few red ones) some additional red light was supplied by a normal bulb. Under such conditions, as is also borne out by FoRTANIER's experiments, an almost normal growth is obtained.

Observations were made on emergence, development, duration and intensity of flowering and the amount of pods formed.

Since at certain (low) temperatures there was very little or no flowering, so that these plants remained quite green, the experiments were stopped when the plants in one cabinet had entered the dying-off stage. The temperature of all cabinets remained constant within $1^{\circ} \mathrm{C}$ throughout the experiments.

\section{Results}

Germination. Since the seeds of the Schwarz 21 variety had been laid out in a pre-germinated condition there was no point in making observations of the emergence in this case; this was only done with the other two varieties. The results are shown in Table 1.

It should be noted that no observations were made at a temperature of $18^{\circ} \mathrm{C}$ as, although germination occurred at this temperature, there was no subsequent development.

Table 1 Number of days from date of sowing to emergence of the cotyls.

\begin{tabular}{|c|c|c|}
\hline Temp. & Mallorca & Ukraine \\
\hline $\begin{array}{l}21^{\circ} \mathrm{C} \\
24^{\circ} \mathrm{C} \\
27^{\circ} \mathrm{C} \\
30^{\circ} \mathrm{C} \\
33^{\circ} \mathrm{C}\end{array}$ & $\begin{array}{r}14 \\
7 \\
5 \\
5 \\
5\end{array}$ & $\begin{array}{r}12 \\
7 \\
5 \\
5 \\
4\end{array}$ \\
\hline
\end{tabular}

These figures clearly demonstrate the retarding effect of the lower temperatures, although both varieties behave in practically similar fashion.

Flowering. Notes were made of the number of days elapsing between the date of sowing and the commencement of flowering (viz. the appearance of the first flowers), whereby the actual figures for the Schwarz 21 variety were augmented by three days on account of the use of pre-germinated seed. The results are summarized in Table 2. 
Table 2 Number of days from date of sowing to flowering.

\begin{tabular}{c|c|c|c}
\hline Temp. & Schwarz 21 & Mallorca & Ukraine \\
\hline $21^{\circ} \mathrm{C}$ & - & 81 & \\
$24^{\circ} \mathrm{C}$ & 64 & 48 & 42 \\
$27^{\circ} \mathrm{C}$ & 42 & 31 & 32 \\
$30^{\circ} \mathrm{C}$ & 33 & 24 & 27 \\
$33^{\circ} \mathrm{C}$ & 51 & 30 & 24 \\
\hline
\end{tabular}

The Indonesian and Ukrainian varieties failed entirely to flower at $21^{\circ} \mathrm{C}$ within the time span of the experiments. Evidently the commencement of flowering depends greatly on the temperature. It is noticeable that the decrease in the number of days from sowing to flowering in the Ukrainian variety continues up to the maximum temperature, whereas in the other two varieties an increase in number is observable. This state of affairs is illustrated by figures 1 and 2 which show a series of typical plants of the Mallorca and Ukraine varieties grown at the successive temperatures from $21^{\circ}$ to $33^{\circ} \mathrm{C}$. Unfortunately no photo is available of a similar serier of plants of the Schwarz 21 variety. These photos show that in the case of the Mallorca variety maximum growth occurs in the region of $30^{\circ} \mathrm{C}$, whereas in the case of the Ukraine variety it is clearly in the region of $33^{\circ} \mathrm{C}$.

Observations made on flowering are shown in figures 3,4 and 5. The curves are cumulative curves of the average number of flowers per plant per day. Unfortunately in the case of the Ukraine variety these observations had to be terminated 56 days after sowing owing to special circumstances. The plants were allowed to grow in the usual way and were harvested at the same time. It can, in fact, be seen from Fig. 5 that anyway at temperatures of $30^{\circ}$ and $33^{\circ} \mathrm{C}$ the intensity of flowering was obviously on the decline. As stated

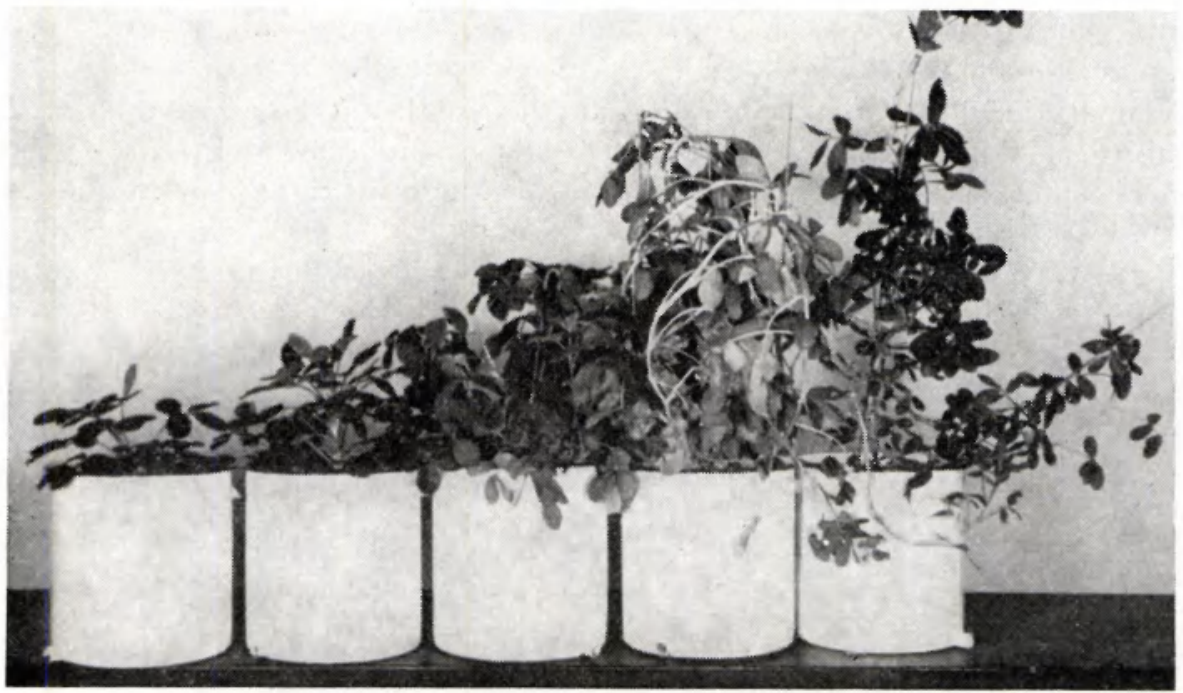

Fig. 1 Piants of the Mallonca vamety ghow at $21^{\circ}, 24^{\circ}, 27^{\circ}, 30^{\circ}$ and $33^{\circ} \mathrm{C}$ (FROM L. TO R.). 


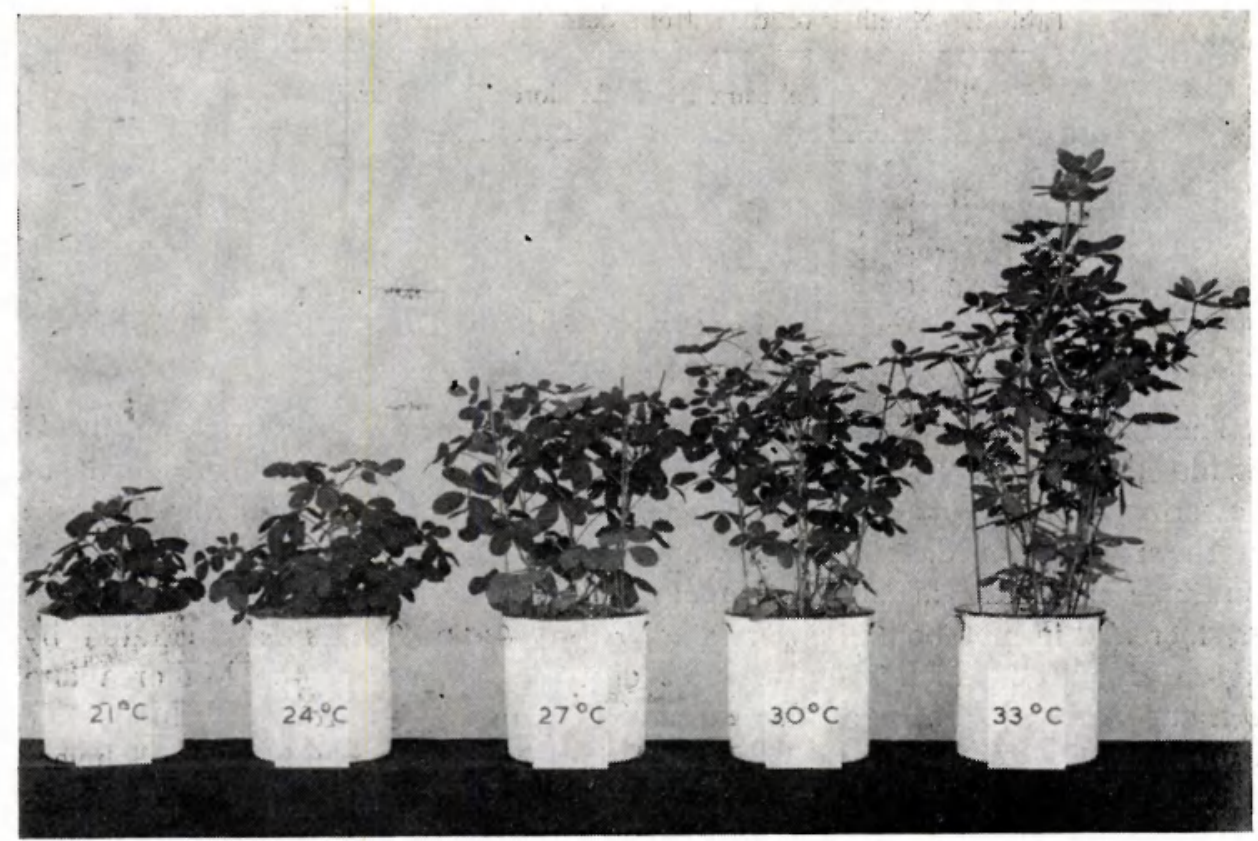

Fig. 2 Plants of the Ukraine variety ghown at the successive temperatures FROM $21^{\circ}$ TO $33^{\circ} \mathrm{C}$.

earlier, the plants were generally harvested whenever the plants in one cabinet showed signs of dying-off, whereas the plants in the other cabinets could still be in full bloom. It would, however, have taken too much time to allow these plants to flower and ripen to the fullest extent. In the case of the Indonesian and Mallorca varieties the flowering observations were continued until harvest, but even in this instance it was found that the flowering of plants which had grown up at the higher temperatures had already ceased, whereas at the lower temperatures the plants were still in full bloom.

Comparison of the graphs reveals that the gradient of the curves, viz. the intensity of flowering, is not everywhere the same. Flowering usually commences somewhat earlier in the case of the Mallorca variety but is far less

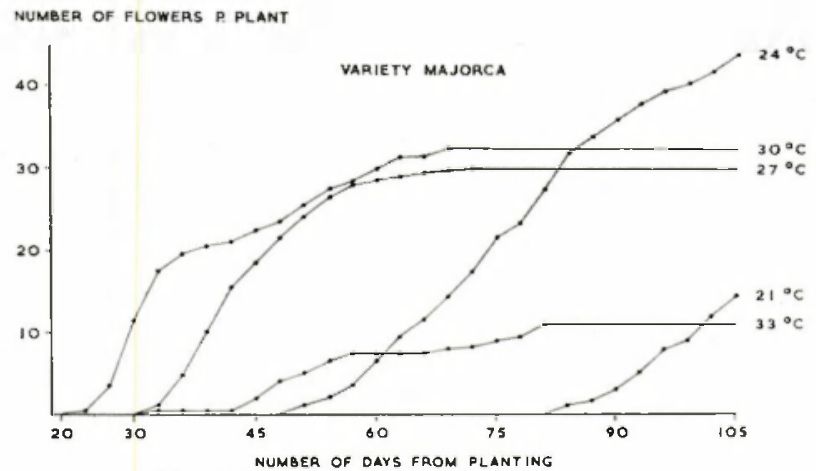

Fic. 3. 


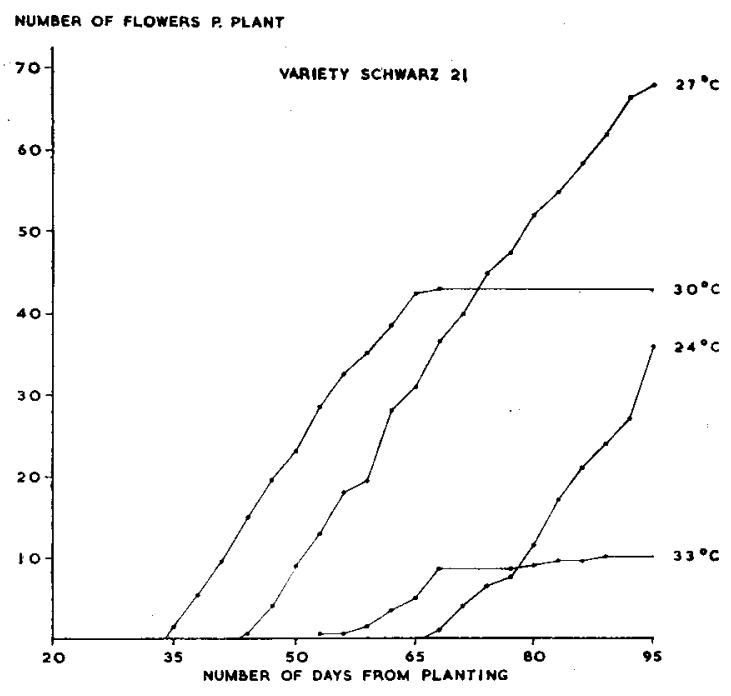

Fig. 4.

Fic. 5.

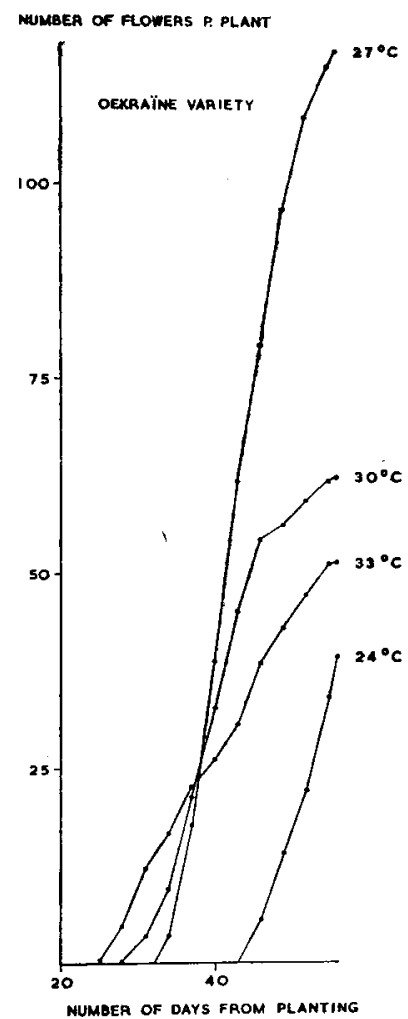

luxurious than in the other varieties. In the Ukraine variety the curves rise very steeply, but this is due to the large number of flowers produced.

Number of pods. As is already mentioned, the plants were harvested whenever the plants in one cabinet, or plants from different cabinets, showed signs 
of dying-off. The ripe pods formed up till this moment illustrate the production capacity of the plants at the given temperature within a certain timelimit. Only wholly ripened pods were counted, viz. those containing fully developed seeds. The results of these counts are listed in Table 3.

Table 3 Average number of pods per plant on harvesting.

\begin{tabular}{l|r|c|r}
\hline Temp. & Schwarz 21 & Mallorca & Ukraine \\
\hline & & & \\
$21^{\circ} \mathrm{C}$ & $\overline{\mathrm{C}}$ & $\overline{-}$ & $-\overline{2}$ \\
$24^{\circ} \mathrm{C}$ & 0.75 & 4.75 & 20.2 \\
$27^{\circ} \mathrm{C}$ & 4.25 & 6.5 & 25.4 \\
$30^{\circ} \mathrm{C}$ & 3.75 & 7.5 & 17.8 \\
$33^{\circ} \mathrm{C}$ & 1.25 & 1.7 & 6.2 \\
\hline
\end{tabular}

As the varieties differ so extensively in number of pods formed and moreover in the size of the pods direct comparison is not possible. It is, however, possible to compare the effect of different temperatures on the same variety. In the Indonesian variety the optimum lies between the temperatures of $27^{\circ}$ and $30^{\circ} \mathrm{C}$. This is also true for the Mallorca variety, but to a far less marked degree as there is even a certain amount of production at $24^{\circ} \mathrm{C}$. In the case of the Ukraine variety the optimum is obviously lower, more pods even being produced at $24^{\circ} \mathrm{C}$ than at $30^{\circ} \mathrm{C}$. No single variety produced a ripe pot at a temperature of $21^{\circ} \mathrm{C}$ which temperature evidently was too low. It can also be seen that in the case of all three varieties a temperature of $33^{\circ} \mathrm{C}$ is too high for good pod formation. These points are clearly illustrated by figures 6 ,

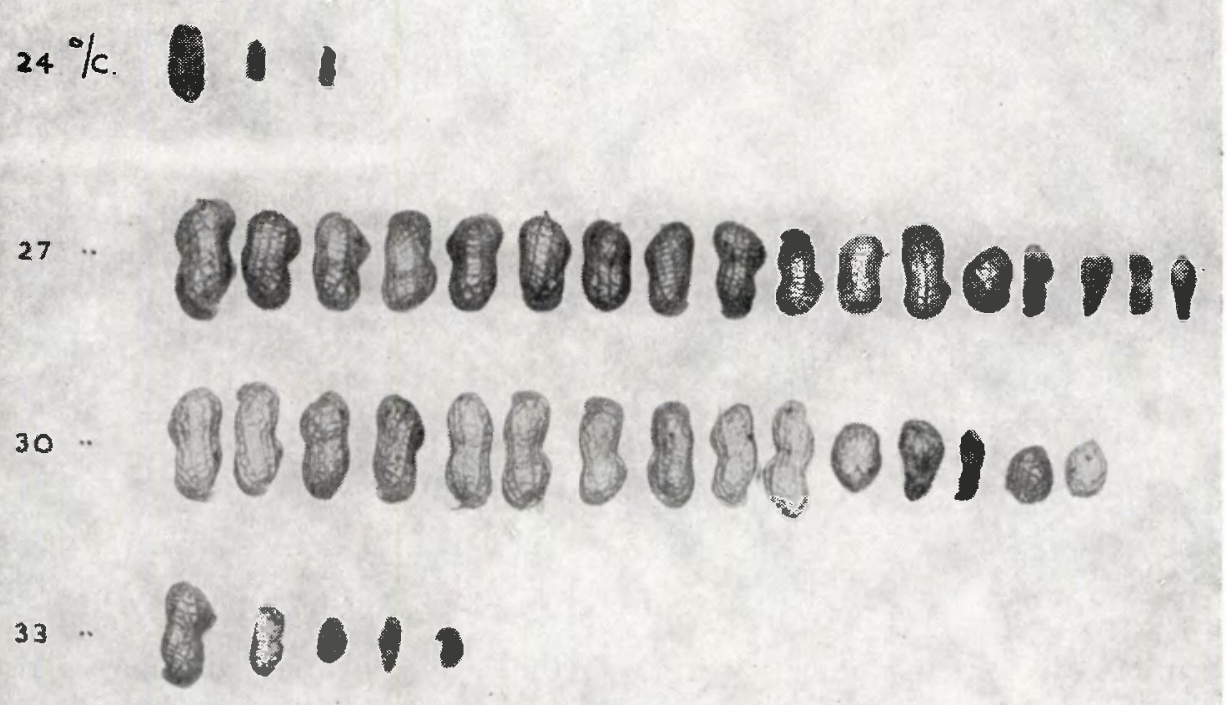

Fig. 6 The pods produced by the plants of the Schwarz 21 valiety grown at the SUCCESSIVE TEMPERATURES FROM $24^{\circ}$ TO $33^{\circ} \mathrm{C}$. 


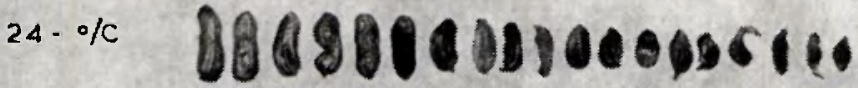 \\ $27 . \%$

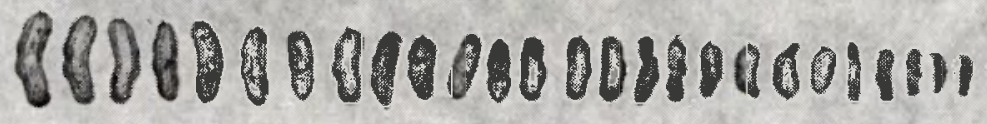

$30 . \%$

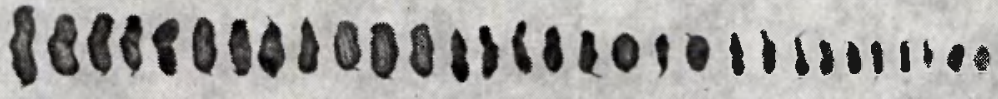

$33 . \% 8001$

Fig. 7 The pods phoduced by the plants of the Mallorca variety grown at the SUCCESSIVE TEMPERATUHES FROM $24^{\circ}$ TO $3.3^{\circ} \mathrm{C}$

\section{$24 \%$

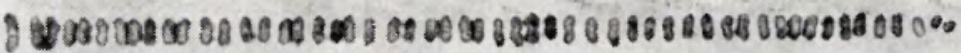

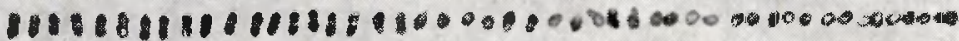 \\ $27 \circ / C$

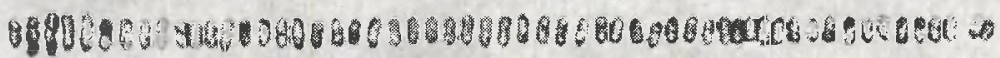

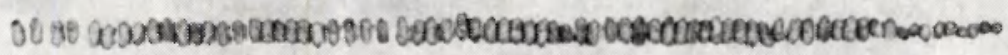

$30 \%$

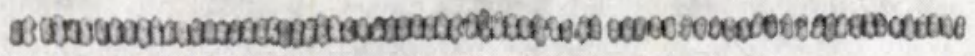

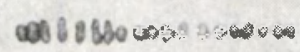

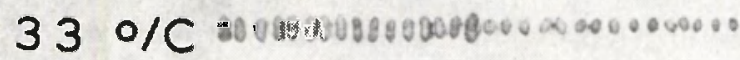

Fig. 8 The pods producen by The plants of the Ukraine variejy girows at the SUCCESSIVE TEMPERATURE FROM $24^{\circ}$ TO $33^{\circ} \mathrm{C}$. 
7 and 8 in which the pods produced by the plants at a given temperature are grouped together. The photos also show that there is a greater production of single-seeded pods at non-optimum temperatures, indicating that difficulties existed even at pollination or at the early stages of fruit-setting.

\section{Discussion}

Inspection of the effect of temperature on the various stages of development reveals the following pattern.

Provided the moisture absorption being adequate the rate of germination within a given temperature range increases with increasing temperature. MoNTENEz found an optimum at $33^{\circ} \mathrm{C}$ in the temperature range of $19^{\circ}-39^{\circ} \mathrm{C}$ in which he germinated his seeds. He also found that a constant temperature was more conducive to germination than differences in day and night temperatures.

ForTANIER obtained optimum germination of the Schwarz 21 variety at $30^{\circ} \mathrm{C}$ in petri dishes, against at $27^{\circ}-29^{\circ} \mathrm{C}$ in the soil. Our own experiments showed that there is little difference at temperatures in the range $27^{\circ}-33^{\circ} \mathrm{C}$.

According to ForTanier the groundnut ceases to grow altogether at $20^{\circ} \mathrm{C}$. Our own experiments did show that with all three varieties there was actually germination at $18^{\circ} \mathrm{C}$, although no subsequent growth. At $21^{\circ} \mathrm{C}$, there was even some slight growth but a certain degree of flowering only occurred in the Mallorca variety. No fruit set was observed at this too low temperature.

Catharinet also worked at constant temperatures with seeds of a Bambey selection number and found a temperature range for germination between $24^{\circ}$ and $38^{\circ} \mathrm{C}$, with an optimum at $32^{\circ} \mathrm{C}$. At this optimum he found a $100 \%$ germination after only 48 hours.

For the vegetative growth ForTanien observed an optimum at about $30^{\circ} \mathrm{C}$ with the Schwarz 21 variety, JACOBS an optimum at $26 / 27^{\circ} \mathrm{C}$ with a Valencia variety, and ALEGre an optimum at $30^{\circ} \mathrm{C}$ with a Senegal variety. In the varieties employed by ourselves we found, like ForTANIER, that the optimum growth of Schwarz 21 was in the region of $30^{\circ} \mathrm{C}$, as was also the case with the Mallorea variety, whereas the optimum of the Ukraine variety is obviously in the region of $33^{\circ} \mathrm{C}$.

The effect of temperature on the flowering of the groundnut will be chiefly reflected in the flower development. The vegetative and generative organs of the groundnut are developed simultaneously, so that a normally developed plant will equally flower in the normal way. So it is possible that temperature has an indirect effect on flowering because growth is retarded at unfavourable temperatures. JACOBS found a distinct retardation of the beginning of flowering at lower temperatures.

Our graphs show that the beginning of flowering, viz. the appearance of the first flower, is very much influenced by the temperature. It can be assumed that in the tropics usually the groundnut flowers 30 days after sowing. ForTANIER found in his experiments that flowering occurs earliest at an average temperature in the range $25^{\circ}$ to $35^{\circ} \mathrm{C}$, it being unimportant how this temperature is distributed over either day or night provided the difference does not greatly exceed $10^{\circ} \mathrm{C}$. In temperature combinations with equal average temperatures flowering is usually earliest in the combination having the least 
difference between the day and night temperature. At average temperatures of below $23^{\circ} \mathrm{C}$ and downward he found an increasing number of days between germination and first flowering. Our own results are in substantial agreement with this; we encountered a difference in the Schwarz 21 variety in which an increase in the number of days between sowing and flowering was again noted at $33^{\circ} \mathrm{C}$. It would seem that a slight difference between the day and night temperature in FortaniER's experiments was conducive to early flowering. Consequently sudden temperature drops exceeding the limit specified by FORTANIER will exert an unfavourable effect on flowering. Thus BouFFIL noticed that a reduction in the number of flowers occurred two days after a sudden fall in temperature. Niclaes and DeMol found an obvious correlation between the number of flowers and the temperatures in the period from 10 days before commencement of flowering to 20 days after.

Our results show that a constant temperature is of great influence on the number of fruits formed. In the case of Schwarz 21 the optimum lies between $27^{\circ}$ and $30^{\circ} \mathrm{C}$, the same holds more or less for the Mallorca variety, whereas the optimum is distinctly lower with the Ukraine variety. The results obtained show that the temperature tolerance is smallest in the tropical variety Schwarz 21. The Mallorca variety exhibits rather more tolerance as regards the number of pods, and the Ukraine variety still more. It would therefore appear that the tolerance for higher temperatures is increased with the possibility to cultivate the plant at higher latitudes.

From their results Niclaes and Demol. conclude that the groundnut exhibits thermoperiodicity. ForTanier, however, arrives at the conclusion that this plant exhibits no thermoperiodicity, a view which is shared by PnÉvor. Our own experiments also show that no fluctuation between day and night temperatures is required for normal growth and flowering. The fluctuations in the intensity of flowering found by Niclaes and Demol, as well as by SMith and Bolhuis, may be explained quite satisfactorily in another way.

\section{ConClusions}

The growth, flowering and fruit set of all three bunch varieties used in the experiments were found to be very clearly influenced by the temperature. It was found that at temperatures below $24^{\circ} \mathrm{C}$ growth was always greatly retarded; there was no flowering and hence no fruit set. A constant temperature of $33^{\circ} \mathrm{C}$ was found to be equally unfavourable, leading to increased vegetative growth which was not, however, reflected in an increased number of pods. Between these temperatures the optimum was found to lie between $27^{\circ}$ and $30^{\circ} \mathrm{C}$ with an Indonesian variety, at $27^{\circ} \mathrm{C}$ with a Mallorca variety, and even somewhat below this temperature with a Ukraine variety. Of the three varieties the Indonesian one was found to exhibit the smallest temperature tolerance, in the Mallorca variety the tolerance was somewhat greater, while the Ukraine variety showed the maximum tolerance. The results obtained afford no indication of thermoperiodicity in the groundnut.

\section{ACKNOWLEDGEMENT}

The authors are indebted to Mrs. Clenx and van Pol for their assistance with part of the experiments. 


\section{REFERENCES}

Alegre, G.: Contribution a l'étude du photopériodisme de l'Arachide en relation avec la température. L'Agronomie Tropicale 12, 3 (1957) p. 494-507.

Arant, F. S., Bledsoe, R. W. et al.: The Peanut, the unpredictable legume. The National Fertilizer Association, Washington (1951).

Bouruis, G. G.: Some observations on the fruiting of the groundnut. Report of the XIVth International Horticultural Congress Netherlands (1955) p. 1482-1484.

- - : Observations on the flowering and fructification of the groundnut, Arachis hypogaea L. I. Netherlands Journal of Agricultural Science 6, 1 (1958) p. 18-23.

- - : Idem II. Netherlands Journal of Agricultural Science 6, 4 (1958) p. 245-248.

- - : Idem III. Netherlands Journal of Agricultural Science 7, 1 (1959) p. 51-54.

Bouffir, F.: Biologie, Ecologie et Sélection de l'Arachide au Sénégal. Ministère de la France d'Outre Mer, Bulletin Scientifique 1 (1947) p. I-104.

Catharinet, M.: Quelques données sur la germination de l'arachide, étude de la température optimum. Ann. Rech. Agron. Bambey, Année 1956. Bull. Agron. no. 16, Min. France Outre Mer.

Fortanier, E. J.: De beïnvloeding van de bloei bij Arachis hypogaea L. Thesis Wageningen (1957) p. 1-116.

JAcoBs, W. P.: The growth of peanut plants at various diurnal and nocturnal temperatures. Science, Washington 114 (1951) p. 205-206.

Montenez, J.: Recherches experimentales sur l'écologie de la germination chez l'Arachide. Publication de la Direction de l'Agriculture, des Forets et de l'Elevage. Bruxelles (1957).

Niclaes, J. and J. Demol: La floraison de l'Arachide dans les conditions climatiques de Bambesa. Landbouwkundig Tijdschrift voor Belgisch Congo 49, 6 (1958) p. 1501-1512.

Prévor, P. : Croissance et développement de l'Arachide. I.R.H.O. Série Scientifique 4 (1950).

Shear, G. M. and L. I. Miller : Factors affecting fruit development of the Jumbo runner peanut. Agr. Journ. 47 (1955) p. 354-357.

SMrth, B. W. : Arachis hypogaea. Aerial flower and subterranean fruit. Am. Journ. Bot. 37 (1950) p. $802-815$.

- - :Arachis hypogaea. Reproductive efficiency. Am. Journ. Bot. 41 (1954) p. 607-616.

TARDieu, M. : Contribution à l'etude écologique de la floraison chez l'Arachide. Bull. Agron. du Min. de France d'Outre Mer 11 (....).

YARBrough, J. A. : Arachis hypogaea. Seedling growth rate. Am. Journ. Bot. 37 (1950) p. $779-785$. 